\title{
School Library Design, Facilities and Resources for Sustainable Cognitive and Social Development of Students: An Evaluative Case Study
}

\author{
Paulette Stewart \\ The Department of Library and Information Studies \\ The University of the West Indies, Mona \\ Kingston 7 \\ Jamaica \\ paulette.stewart@uwimona.edu.jm
}

\begin{abstract}
The purpose of this study was to examine the circumstances that prompted the school administrators to construct a new library that included modern library spaces, resources and facilities, to find out the strategies used to build the new library and to determine the perceived effects that the new spaces, resources and facilities have on students' cognitive and social development. This research took an evaluative case study approach. Purposive sampling was used to select the school principal, the school librarian and eight students. The principal and school librarian were interviewed and open ended interview schedules were administered to the students. The findings revealed that the design of the library, the resources and the facilities had a positive impact on students' cognitive and social development. It was recommended that the Ministry of Education Youth and Information redesign or construct similar school libraries on a phase basis because of the positive educational impact.
\end{abstract}

Keywords: school library design, library design and cognitive development, library design and social development, library resources and cognitive development, library facilities and social development 


\section{Introduction and background}

Internet access, electronic media, computer technology, and other forms of modern-day advancements have had a profound effect on the design of libraries (Whole Building Design Guide 2010, para. 1). The Whole Building Design Guide posits that the primary goal of effective library design and space planning is that the facility must respond to the needs of its service population. The Chicago Architecture Foundation, (2013, para. 3) points out that re-imaging a school library can involve redesigning of the interior of the existing library space, expanding the existing space, or designing a completely new addition to the school building. This design should contain all the spaces required for a typical school library- a variety of seating options for students (inside and out), as well as space for book and media storage, the librarian, computer areas, audio/visual labs, and meeting spaces. In addition to these there can be an inclusion of a cafe, information kiosk, or a workshop area. The re-designed library should include ideas from both old and new libraries and there should be consideration of sustainability issues and the environmental impact of the design. As a space, the school library should be designed with spaces to facilitate the development of students' interpersonal, academic and problem-solving skills while it explores new ways of learning that will provide a rich and dynamic learning experience for students.

\section{Theoretical framework underlying learning spaces}

Van and Chism (2006, p. 2.2) quote Monahan who posits that the term "built pedagogy" refers to "architectural embodiments of educational philosophies which means that the ways in which a space is designed shape the learning that happens in that space. Review of research on how space makes individuals feel by Van and Chism cited Scott-Webber (2006) explains that when space is related to knowledge creation, communication and application, the space configurations exert powerful influences on these activities. Van and Chism (2006) further explain that environments that offer experience, stimulate the senses, encourage the exchange of information, and provide opportunities for rehearsal, feedback and application, and transfer are most likely to support learning. In addition, they also mention that social constructivists assert that the social setting influences learning.

\section{Significance of the research}

Since the literature on built environment shows connections between learning spaces and student learning outcomes. Therefore the findings can influence the Ministry of Education Youth and Information and schools' administrators to build or re-design their school libraries 
similarly to the selected library because of the perceived evidence of how the design of modern library spaces can affect students' cognitive and social development. The findings can also be used as evidence that relevant library resources and ideal library facilities are key components that promote teaching and learning.

\section{Review of Literature}

\section{Designing a school library}

Nelson and McConachie (2008, p. 20), set out five design elements that should guide the design of new and renewed high school library space. They note that in designing this type of library the primary aim is to attract students to the library while the secondary aim is to store materials. The first design element is the space for teaching, learning and production of knowledge which is more important than space for storing materials. This means that when designing a school library the teaching and learning goals must take precedence. This is critical as these goals drive the criteria for evaluating the space devoted to books, media technology, networked content, offices, and formal and informal teaching areas. This consideration is important because high school students need space other than the generic classroom to read, view, write, talk and produce evidence of their learning. A centralized library is an ideal work space for this to happen.

The second design element is that the library must support multiple ways of teaching and learning. The goal for this type of design is to make spaces within the library for individual work, group work which can be done quietly or collaboratively, with or without networked resources, and with or without librarian instruction and help. The third design element is the collection development policy that should influence library space needs. The goal of having resources on a wide variety of subjects is no longer necessary because of the ubiquitous web-based content in that if the library has the right licenses to electronic databases the school library can provide access to far more content than the library can purchase and store.

The fourth design element addresses the content and services of the library. This means that the Intellectual content and some library services should be delivered through a library's networked infrastructure rather than as physical media stored within the library. Nelson and McConachie stress that the highest priority should be given to the quality of the library's electronic infrastructure. The fifth design element is that the library must be grand, beautiful and inspiring. Nelson and McConachie describe this as grand, inspiring, beautiful and dignified with ample unencumbered floor area, generous spatial volume, and abundant natural light. They argue that the library's location, size, technology infrastructure and 
aesthetic quality attract students to the school's signature academic space. They also emphasize that all adolescents deserve school library space which is out of the ordinary and that an inspiring library space elevates the importance of academic work.

According to JISC (2009, p. 3) an educational building, such as a school library is an expensive long-term resource. When designing the building, the spaces need to be flexible to accommodate both current and evolving pedagogies, future-proofed to enable space to be re-allocated and reconfigured, creative to energize and inspire learners and tutors, supportive to develop the potential of all learners, and enterprising to make each space capable of supporting different purposes.

\section{Strategies used for designing a school library}

JISC (2009, p. 31) mentions that consultation with key stakeholders on their aspirations for the new spaces and experiences with the limitations of the old ones will build an overview of dominant views and beliefs and show where leadership is required. The stakeholders in a school setting are school boards, administrators, teachers, parent and students. The school board, administrators and staff should ensure that the designs of physical spaces are linked to the institution's strategic vision for teaching and learning and that this is articulated in every detail of the design and shared with all stakeholders, including learners.

\section{Effects of library spaces on cognitive and social development}

Taylor (2008, p.32), argues that "architects must integrate their design knowledge with an understanding of interdisciplinary learning and the developmental needs and learning styles of students, while at the same time educators, parents and students must broaden their awareness of the built, natural and cultural environment and its potential as a learning tool" Taylor also points out that research shows that the quality of the physical environment affects the quality of the learning. Nelson and McConachie $(2008$, p. 21) emphasize that high school libraries need spaces for individuals, small and medium-sized groups, and sometimes very large groups. These groups are likely to talk and would like an area where conversation is acceptable.

\section{Research objectives are, to:}

1. Examine the circumstances which prompted administration to construct a new library.

2. Assess the strategies used to design the new library.

3. Discover how the resources were obtained to build the new library 
4. Find out if there is an increase in the level of library usage.

5. Determine the perceived effects that the library design, resources and modern facilities have on students' cognitive and social development.

\section{Research Design}

This case study took the qualitative methodology approach because the study is focused on a specific case. The data were collected by interviewing the principal and the librarian. An open ended interviewed scheduled were given to the students to complete as it was not possible to have the planned focus group with them. Three unobtrusive observations of the library and the students using the library were done because Better Evaluation (n.d.) suggests that to capture as many details as possible several observations should be conducted. The data were collected over a period of six weeks. The data were analysed by identifying the themes and patterns and then organizing them into coherent categories that were summarized to bring meaning to the text (Taylor -Powell and Renner, 2003, p.2).

\section{Sample}

Purposive sampling was used to select eight students from grades 10 -13 (2 from each

grade). The Tongco's strategy was used to recruit the students. This strategy allowed for the researcher to develop a set of criteria on what would constitute a good participant, and then ask the teacher librarian to select participants consistent with the criteria (Tongco, 2007, p.151). The following criteria was given to the librarian for the selection of the participants. Students should:

1. Be in grades $10-13$

2. Have knowledge and experience of using the old and the new libraries.

3. Be willing to respond to questions in a group setting.

4. Be a mix of male and female

5. Be interested in participating, and

6. The parents of these students should be willing for them to participate

\section{Limitations}


There were 148 high schools in Jamaica but this study will only be conducted in one because this is the only high school that had a newly built library with modern spaces. The findings will not be generalized, although they can be used as good examples for those institutions that seek to re-design or re-build their school libraries.

\section{Findings and analyses}

\section{Demographic data.}

At the time of the research the school was a 56 year old coeducational institution with a population of 1,493 . When the school was built a two-storey library was constructed away from the classrooms and other school facilities. This library opened from 8 a.m. to 4 p.m. The eight students reported that they used this library between one to four years. Opening hours were from 8 a.m. to 4 p.m. from Monday to Friday.

\section{What prompted the administrators to construct a new library?}

Before being appointed to the post, the principal conducted a survey among students to find out how satisfied they were with their school. The findings showed that the majority of students wrote "we do not have a library". The researcher believes that the library might not have been meeting the information and recreational needs of these students. This response had a profound and devastating impact on the principal who decided that something had to be done about the library. The findings of the research also made her acutely aware of the digital divide that existed among the students in that $30 \%$ of them had no Internet access at home. She remarked that, "I could not in good conscience give priority to the building of a new auditorium over a library because without the access to library resources and the Internet these students would likely perform less academically than those who had access".

The principal declared that she had no idea of what a modern school library looked like and just about the time when the idea was discussed among the administrators, she was invited by the Dean of Harvard College to visit the institution. She took the opportunity to tour the library as well as other school libraries in Boston to see how they were constructed. Her husband who was an architect asked pertinent questions about the various spaces observed and discovered that the spaces catered for trans-disciplinary and collaborative learning. They saw the need for the library to be technology rich, with an information technology expert. Altogether, they learned that school libraries should be inviting spaces for the $21^{\text {st }}$ Century learner. 


\section{The planning phase and cost}

The researcher's observation and interview data will present the design, resources and facilities that were considered in the planning phase. It was decided to situate the library in a more central position although it would still be unattached to classrooms and other school amenities. It is positioned a short way from the round-about drive way and therefore a circular-shaped building was agreed on to match this type of drive way. The library has three floors. The first floor has a very large reading room with seven computers at two stations, tables and chairs, bean bags and sofas and a number of bookshelves stocked with books relevant to the curriculum placed against the walls.

The second floor, the smallest of the three floor provides entrance to the library by steps and ramp and consist of the reference desk, baggage area, one student room and two computer stations with five computers each, a wedged-shaped chair for relaxation while waiting on a computer and the photocopying machines. The librarian's reference desk, the information technology staff office as well as a beautiful showcase in the centre that displayed important notices and current books that were purchased are also on this floor. A ramp is at one side for physically challenged students to enter and leave the first floor.

The third floor can be entered from steps on either side of the building. It has another very large reading room with additional reference desk with a computer for the library volunteers who were either students, past students or parents whose task it is to assist the librarian in offering reference services. There are three other computer stations that have a total of seven computers. The recording studio is at the far corner and it is used by teachers and students to record lessons and assignments and to support the flip classroom initiative by the school. Also on this floor are four study rooms fitted with computers and overhead projectors, a large seminar room that is used for teaching purposes and for collaborative and individual work. The well-stocked bookshelves on this floor are placed in one section. A balcony for relaxation and study as well as two bathroom facilities were on this floor. An elevator was also to be included in the building.

The architect decided to use the green building feature which means that the building was constructed in such a way that it uses natural light and collects water from the roof to water the garden around the library. This daylight feature provides an abundance of natural light that only a few lights had to be turned on. The heat effect keeps the building cool as the air flows through the library. One large overhead ceiling fan was in operation. Another green feature is the joint use of the facilities. The lecture room with computer and overhead 
projector was built for teachers to have classes in the library that require the use of these equipment. In addition, the recording studio is used by both teachers and students for academic purposes. The open-space concept design of the library made it extremely attractive, uncluttered and inviting. The view of the first and second floor from the third floor gives the viewers a grand, beautiful and inspiring picture of these floors.

The planning stage involved the administrators, teachers and very importantly the librarian who gave the architect certain specific instructions relating to the various spaces that were necessary and the ideal position in which they were to be situated. The planned library design of is consistent with the five design elements mentioned by Nelson and McConachie (2008).

\section{How the funds were garnered}

The principal confessed that the construction of a new library was not in the School's Development Plan. There was a search for a major donor. A prominent citizen whose son attended the school but die shortly after graduation was contacted. The idea of building the library in the memory of his son was discussed with him and he accepted. To avoid nepotism, her husband could not be employed to construct the building. However, he created an architectural brief based on what was seen of other libraries for the architect who would be employed. The major donor selected the architect who incorporated the architectural brief into his design.

The estimated cost for construction was US\$700,000 or JA $\$ 5.3 \mathrm{M}$ according to the exchange rate at that time. The major donor pledged to give US $\$ 350,000$ and told the school to match this amount. A fundraising drive began. Donors were identified and were labelled based on the amounts that each contributed. The following donors names were written on silver plaques embedded on the inside wall at the entrance of the library and juxtaposed to the photograph and the profile of the major donor son. Cornerstone donors- US $\$ 50,000$; Leader donors US $\$ 20,000$ - US $\$ 49,000$ which included the school's home school association; major donors US $\$ 10,000$ - US $\$ 19,999$; and friends of the school US $\$ 999-U S \$ 1,000$ which included the class of 2010-2013. Other donors' names were placed on beautiful brownish red tiles on the walls outside of the library. Some of these has sentimental phrases such as "forever in our memories", "gone but never forgotten" and "always in my heart". The school was able to garner sufficient funds to complete the building except for the purchasing and installation of the elevator and the tiling of the ground floor. 
Hinds (2015) in a report on how to build a library from scratch cited that she had to seek grants from various individuals. She also used the method of seeking donors and commented that, "DonorsChoose.org has been good to me: my colleagues and I have raised over $\$ 25,000$ in materials for our library". Observation showed that numerous donors were involved as Celsus: A Library Architecture Resource (n.d. para 11) indicates, "No one funding source will typically cover all of the costs associated with library construction."

\section{Difference in level of use by students}

The librarian responded that approximately 250 students used the library each day and this increased when major assignments were due. This was in comparison to the average of 30 students who used the old library daily. The participants indicated varying levels of use as shown in Table 1.

Table 1: Level of Use in the Old and New Library.

\begin{tabular}{|l|l|l|}
\hline \multicolumn{2}{|l|}{ Old Library } & New Library \\
\hline Students & Level of use & Level of use \\
\hline 1 & Occasionally & Once a week \\
\hline 2 & One per week & Four times per month \\
\hline 3 & A few hours & Two times per week \\
\hline 4 & Once every 2 months & Almost every day \\
\hline 5 & Once a week & One-to-two days per week \\
\hline 6 & Rarely & Everyday \\
\hline 7 & One to two times weekly & Two to three times weekly \\
\hline 8 & Everyday & Once a week \\
\hline
\end{tabular}


All students reported that the increase in use was not only as a result of the design of the library but that there were sufficient, faster and more reliable computers connected to printers that have better printing quality. In addition, there was better Wi-Fi connection, the bean bags that tired students can rest on between classes and that the library had all the resources they needed. They also commented that the library was now closer to the classrooms.

The librarian added that the huge increase in the number of students using the new library was that they were attracted by the design, the resources and the comfort that the library offers. This was also due to the extended opening hours of the library meaning that the new library now opens from 7 a.m. to 6.00 p.m. instead of 8 a.m. -4.00 p.m. The librarian

explained that parents were scheduled to be in charge of keeping the library open from 4.30 p.m. -6.00 p.m. During the observation from 5 p.m. to 6 p.m. this was noticeable.

Not only has the frequency of use increased but also the length of time students stayed in the library. One student wrote "of course" to the question, "Has the length of time you spend in the library increased since you began using the new library?" Five students reported that they stayed in the library for up to $1-3$ hours, and two for $1 / 2$ hour to 3 hours. One students said "As long as my break lasts."

Gretes (2013) cites Small (2010) research finding which states that the library's welcoming, safe, and comfortable environment is a positive influence on library use for both students and teachers. Gonzalez (2016) in her article "How this school library increased student use by 1,000 percent' shared her experience of re-imagining the library space to a place where students did hands-on work as an extension of what was happening their classrooms. This in turn increased the number of users of her library. The reasons students gave for their increased use of the library support this statement.

\section{The reasons for using the old library}

The reasons students gave for using the old library were: one student needed a place to study for examination and to print his assignments while another used it because he did not have a printer at home to print his homework. Another did not have a computer and one remarked that she never used it to do school work, she only went in there to meet with her teacher. Two students mentioned that they used it because they had no Internet access at home, and one used it as a space to sit and do assignments. One student only used it to collect and return rental books. The librarian attributed the low use of the old library to the 
small space and minimal facilities while the students attributed it to poor ventilation, inadequate space and insufficient and slow computers.

The researcher concluded that students stayed away from the old library because it was not fully functional. School libraries that will attract 21 st century leaners who are described as "born digital" and see digital technology as the norm need hi-tech libraries. While the library might have had relevant resources, it seems also that it was not aesthetically appealing to students and did not provide an avenue for collaborative work. As a result of the various social media students are inclined to interact and collaborate and would prefer a space where they can learn in a social context. Nelson and McConachie (2008) fifth element that should guide the construction of a new library also mentioned that adolescents deserve school library space that is out of the ordinary....

\section{How is the new library different from the old?}

Students explained that when the old library was been used, students had to wait a long time to use one of the three computers and sometimes the time "ran out" so they could not do what they wanted. At the time the research was conducted there were 30 computers with modern functionalities and these were attached to the printers. One student indicated that "in the old library, everything was clustered and not enough space to get things done and the library would be packed very quickly".

Students reported that the modern design of the new library resulted in more comfortable space which is better organized, and provided access to a wider variety of current and appealing books without having to rent them. The library was equipped with a portal developed by the librarian that allowed students access to reference information, examination past papers, and academic papers. Also included was faster Internet and Wi-Fi and multi-media technology. Students were fascinated by the recording studio which was available to both staff and students for recording presentation, jingles songs and interviews. Teachers often used it to record lessons for class, and these were also used in flip the classroom where DVDs or lessons recorded by teachers were given to students to be viewed prior to class time. Students without computer access at home could view these in the library. Students also mentioned that there were now study rooms, seminar rooms, and a recording studio and very comfortable furniture. The library also had a comfortable sitting areas both upstairs and downstairs. They also mentioned that the library tends to be busier and louder as it was able to accommodate more students. 
The American Association of School Libraries (AASL) in citing Partnership for the $21^{\text {st }}$ century skills (10), in its comments on school libraries argued that "the physical space serves as an intellectual gymnasium with multiple, flexible spaces that accommodate a variety of learning tasks." In addition, this association mentioned that a, "21st century library is more than just a physical place, of course: it also has a virtual aspect. Many school libraries are creating portals that link their holdings to other appropriate sites and afford 24/7 access to information for their school community" (Partnership for the 21st century skills, n.d. p.10).

During the researcher's observations, the facilities and the resources pointed out by students were evident. Students and teachers were seen using the study rooms and the lecture theatre. It was very obvious that there were only few text books on the tables that students were studying. They had instead their own laptops and smart phones which they were able to use to access electronic information from within the library. The Bring Your Own Devices (BYOD) was necessary as the computers were always heavily used during the researcher's observation. As students used the library it was clear that they were able to converse freely and openly among themselves. They sat around the tables or on the bean bags or the couch, which ever made them more comfortable. Gretes (2013, p. 10) refers to Trilling, 2010 comments that 'Libraries are evolving into 'libratories' - environments where a wide variety of learning activities and projects can take place: project space, design studio, community meeting and presentation space, and research and development lab."

\section{Main reason for they were attracted to the new library}

Students were asked to tell the main reason they were attracted to the new library. The responses indicate that the library has an artistic appeal and had current and relevant resources and modern facilities. Students pointed out that the library was more inviting to study because it had comfortable upholstered seating. They also commented that it was a

good place for completing homework/assignments (without noise) on computer that had printing. They liked that there was access to the Internet and Wi-Fi. Other reasons students used the library were: to meet with peers to complete group projects, to study and "for sleeping, to have "bit of fun", to sit on the lounge chairs or bean bags and read and to enjoy a well needed rest". In addition there was a space to hold club meetings.

\section{What do you like best about the new library?}

Students were asked what they liked best about the new library. They responded by stating that the library was designed with spacious reading rooms that were adequate for students 
to be seated comfortably and do their work. They also liked that, "the library was furnished with 'comfy' furniture which promotes good naps". Three students commented that they liked the new library because of the availability of an abundance of computers and the option to print and photocopy because many students lack these at home. Three students also like the fact that they were able to bring their own devices (BYOD) and that there were adequate electrical outlets to accommodate these. Added to this, one student liked that printing could be done from her own device. Another student commented "as a student with an unreliable printer at home, I like that I can print my assignments easily in this library." Another stated "this library environment gives students the incentive to complete assignments to the best of their ability in the respective deadlines". Two students cited that more space for breathing and reading was available while another acknowledged that more resources were available. One student mentioned that what he liked best was the various forms of multimedia technology.

\section{Perceived impact of the library design, resources and facilities on cognitive development of students}

The school librarian reported that, it was her perception that the library designed, facilities and resources had positively impacted students' cognitive ability. Her perception was based on research conducted on the impact of school library environment on academic performance. Students' library records and her observation showed that students used the library very frequently and their recurrent use of the various resources was likely to help them gain new knowledge. In addition, the students' rooms were fully booked every day meaning that students were meeting together to study or complete assignments/projects collaboratively. The recording studio was always in great demand as student were using it to record assignments that had this requirement.

The school librarian also mentioned that the library facilities contributed to students' learning as the relaxing furniture caused students to spend longer hours in the library to read and study. Students had their individual preference and so some curled up on bean bags or sat on the soft seats to read or do work. The balcony allowed the students a scenic view of the area while studying, and so some preferred to be out there because it provided the ambience for the students who learn best in this type of relaxing atmosphere. She further remarked that, "for those who learn best while listening to soft background music they were provided with headphones or they could use theirs to listen to music while they work in the library". 
The librarians perception is consistent with research findings of Rodney, Lance, and Hamilton-Pennell quoted in Gretes (2013,) which revealed that "Student achievement increases when the library media collection is adequate and students borrow materials frequently; the library media center has computers with access to library resources, online databases, and the Internet..." (13). The findings of other research also mentioned by Gretes $(2013,10)$ showed "that the number of visits to the library can play a part in student achievement and library usage correlates with student achievement and that different types of seating such as easy chairs and straight chairs, and areas for students to be seated together or in private cater to academic achievement."

\section{Effects on Cognitive development as stated by student}

The school librarian's perception was confirmed with the responses given by students as shown in Table 1.

Table 1: Effects of Library Design, Resources and Facilities on student cognition.

\begin{tabular}{|c|c|c|}
\hline Library design & Library resources & Library facilities \\
\hline $\begin{array}{l}\text { "The larger space helps me to } \\
\text { breather better and provide } \\
\text { more space to read and study. } \\
\text { This promotes healthier brain } \\
\text { performance and hence better } \\
\text { academic performance". }\end{array}$ & $\begin{array}{l}\text { "It has increased my homework } \\
\text { grades because of easy access } \\
\text { to research materials." }\end{array}$ & $\begin{array}{l}\text { "Typically, I have a } \\
\text { quieter place to work in." }\end{array}$ \\
\hline $\begin{array}{l}\text { "The library provides me with a } \\
\text { quiet area for me to focus and } \\
\text { complete my tasks". }\end{array}$ & $\begin{array}{l}\text { "Homework can be carried out } \\
\text { easier depending on the subject. } \\
\text { There can be up to } 8 \\
\text { assignments. I get } 100 \% \text { when I } \\
\text { use the library." }\end{array}$ & $\begin{array}{l}\text { "A quiet place to work in } \\
\text { help me to do my best } \\
\text { without being disturbed." }\end{array}$ \\
\hline $\begin{array}{l}\text { "The required spaces are } \\
\text { available for me to focus and } \\
\text { do my work". }\end{array}$ & $\begin{array}{l}\text { "The library has provided me with } \\
\text { a wide array of information that } \\
\text { has allowed me to make my } \\
\text { studies more in-depth. My grades } \\
\text { have improved slightly." }\end{array}$ & $\begin{array}{l}\text { "I am able to do work } \\
\text { when I am at school late } \\
\text { in the evenings, instead } \\
\text { of idling while I wait to go } \\
\text { home and allows me to } \\
\text { remain focus when doing } \\
\text { assignments hence } \\
\text { positively affect my } \\
\text { academics". }\end{array}$ \\
\hline $\begin{array}{l}\text { "The study rooms are quiet } \\
\text { which helps to maintain focus } \\
\text { when doing work". }\end{array}$ & $\begin{array}{l}\text { "My academic success is due to } \\
\text { the creation of this new library as } \\
\text { it is easier to finish the necessary } \\
\text { assignments". }\end{array}$ & $\begin{array}{l}\text { "Working space on the } \\
\text { table is adequate". }\end{array}$ \\
\hline \multirow[t]{2}{*}{$\begin{array}{l}\text { "Due to the space I can find } \\
\text { quiet spaced for myself in } \\
\text { order to completely immerse } \\
\text { myself in my work." }\end{array}$} & $\begin{array}{l}\text { "The computers in the library aid } \\
\text { in research and preparation of } \\
\text { types assignment". }\end{array}$ & \\
\hline & $\begin{array}{l}\text { "The library has helped me to find } \\
\text { information to complete by }\end{array}$ & \\
\hline
\end{tabular}




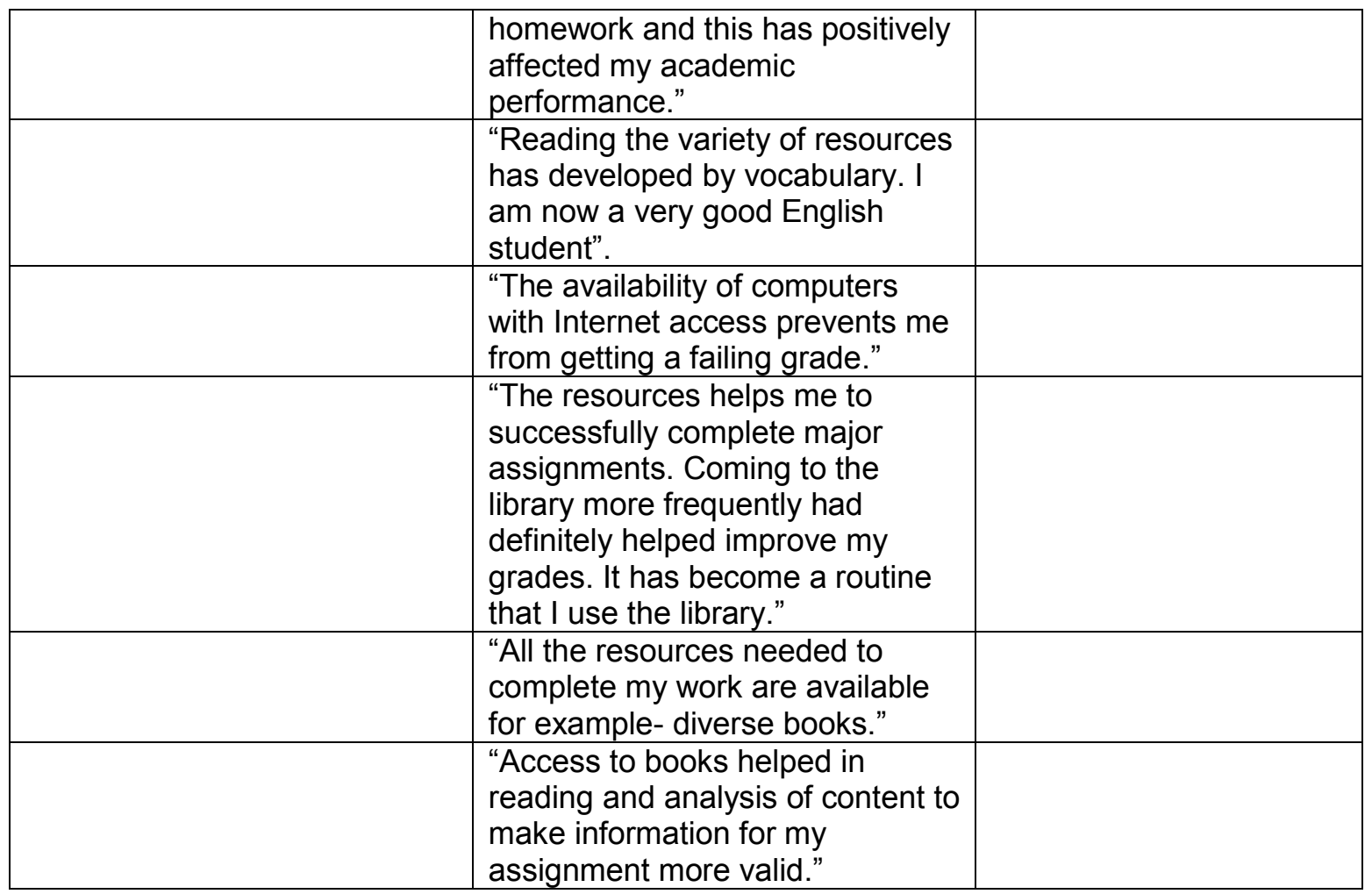

The data displayed in the Table 2 indicate that the library design, resources and facilities impacted positively on students' academic achievement. Research findings on the impact of school libraries on learning conducted by Williams and Morrison (2013) shows that library resources both print and electronic including technology as having a significant contribution to higher test scores and student achievement.

\section{Perceived impact of space on social development of students}

The school librarian also of the view that the design of the library seemed to have a positive impact on students' social development. The reason this conclusion was drawn is that, the student rooms and the lecture theatre provided collaborative spaces for group and club meetings and other social activities that provided free interaction among students and teachers.

Students' responses confirmed the school librarian's perception that the library design had a positive impact on their social development. They mentioned that they were able to have comfortable group meetings in a quiet and tranquil environment which encouraged interaction among peers. They further expressed that the arrangement of some of the tables 
and chairs near the computers facilitated interaction even when assignments were been completed.

\section{Examples of how library space Improve relationship with classmates}

The examples student gave to show that the library design improved their interpersonal relationship were: "We are able to engage in quiet and intelligent discussion in a quiet and safe environment"; "From my experience with group projects, we can all come together and discuss different opinions and research without discrimination along with the occasional fooling around"; "When we have group work we get to bond while working together."

\section{Why choose the library to engage in group activity}

Students explained that they used the library to do group work because there was ample space with chairs, projector, and computers with Internet access were provided for group work and group presentations. Others mentioned that the exclusive meeting rooms helped them to concentrate and so they were able to complete their assignment faster and with fewer mistakes. One student mentioned that the library was chosen to do group activities because the couches were comfortable for her to sit on and groups were able to work undisturbed. Another student remarked, "There are meeting rooms which provide exclusiveness and also furniture which provide comfort". The current, relevant and adequate resources was another reason for using the library for group work and that there were computers nearby to facilitate getting "on the spot" information.

Cesari (2014, p. 46) in commenting on supporting social development in the libraries remarks that when libraries are being designed consideration the social-development needs of adolescents. She explains that this means, finding ways to encourage the development of close, personal relationships among peers by arranging academic spaces, especially libraries to provide students with opportunities to form friendships during the school day. She suggested that this can be done by, "creating conversation zones that should feature soft lounge furniture placed in a grouping around a coffee table or footstools or at the very least, contain tables that accommodate multiple seated students".

How has the general informal and relaxing environment helped you develop socially? 
One student reported that "the comfort relaxes the mind, which in turns relaxes the body. Relaxed minds and body help people to develop socially positively by helping them feeling less frustrated and this helps them to listen to their peers and appreciate what they are saying. This promotes better social relationships". Another mentioned that "The environment helps to create the circumstances for spending time with peers through working together on a piece of work or just to have a 'chill' session in the library".

Additional responses indicated that, "Due to the relaxing environment, it has allowed me to focus and cooperate more with people who I am working with. I am better able to communicate and interact with them outside the library", "With regards to any persons with whom I correspond with presently, the relationships with these individuals have been nurtured in the library setting". The relaxing furniture and technological advances (i.e. bean bags, meeting rooms and the studio) have promoted the togetherness among the student population." "The provision of couches and bean bag chairs in lounging spaces to sit on helps my friends and I to relax and unwind from stress of school life." "It aids in one mental and independent studying in which find myself going to the library more and more, not just for homework completion but studying in my own free will." "The calming and conducive environment makes me enjoy going to the library and doing my work'. One student mentioned that the library environment has not really help him to develop socially.

Suarez (2007) conducted an ethnographic research to find out what students do when they study in the library. He found out that, "Some of the behaviors observed can be grouped together as leisure or social behaviors but these, on the whole, do not seem to distract from academic work being done in the library" (para. 40). He observed that academic learning takes precedence over students' use of cell phone, personal sound devices, or chatting, or napping which seem to promote personal relaxation, and social bonding between students. He added, "students wanted as much physical comfort as possible to help them study. They wanted convenience, quiet areas to get away from others so they could concentrate better and that the nature of their assignments was a powerful factor in their preferences for group study areas".

\section{Conclusion}

It can be concluded that the design of a high school library space is an important and vital element that should be considered when constructing or re-designing a school library. According to the article, School library design (n.d.), the designer has to have an understanding of the different ways students actively engage with learning both individually and socially. It is suggested that the design should be based on research on how students move through spaces .....because physical factors of space and colour directly affect 
learning experiences so there is need take the time to get this right. This is important because the design can include the type of facilities that can attract students to the library as well as provide the necessary spaces for the resources to be displayed attractively.

Altogether, these will improve students' cognitive and social abilities which will prepare them for life beyond high school

\section{Implications}

High school students who are exposed to well-designed libraries with the appropriate facilities and resources are likely to succeed academically as well as socially. This will eventually prepare them to become citizens who are able to function well in society. Teachers and school administrators will value the library as an integral part of the teaching learning experience and students will realize that the library is essential to their learning

\section{Recommendations}

Based on the positive findings of the research, the researcher recommends that the Ministry of Education Youth and Information re-design or construct new school libraries on a phase basis.

Fund raising effort should continue to garner funds for the installation of the elevator to accommodate students who might become physically challenged. 


\section{References}

Better Evaluation. (n.d.) Non-participant observation. Retrieved June 5, 2016, from http://betterevaluation.org/evaluation-options/nonparticipantobservation

Celsus: A Library Architecture Resource. (n. d.). Funding sources for renovating \& building new libraries - United States. Retrieved June 5, 2016 from https://libraryarchitecture.wikispaces.com/Funding+Sources+for+Renovating+\%26+B uilding+New+Libraries+\%E2\%80\%93+United+States

Cesari, L. Arranging a library to support adolescent development. Knowledge Quest.42 (4), (Mar/Apr 2014), 44-48.

Chicago Architectural Foundation. (2013). Discover, design: A student design experience. Retrieved Oct.6, 2014 from http://www.discoverdesign.org/design/instructions/competition2013

Gonzalez, J. (2016). How this school library Increased student use by 1,000 percent. Retrieved June 5, 2016 from http://www.cultofpedagogy.com/school-library/

Gretes, F. (2013). School library impact studies: A review of findings and guide to resources. Retrieved June 6, 2016 from http://www.baltimorelibraryproject.org/wpcontent/uploads/downloads/2013/09/Library-Impact-Studies.pdf

Hinds, J. d. (2015). How to build a school library from scratch. Retrieved June 3, 2016 from http://www.slj.com/2015/03/feature-articles/how-to-build-a-school-library-fromscratch /

JISC. (2009). Designing spaces for effective learning: A guide to 21st century learning space Design. Retrieved Oct. 4, 2014 from http://www.webarchive.org.uk/wayback/archive/20140616001949/http://www.jisc.ac.u $\% 20 \mathrm{k} / \mathrm{media} /$ documents/publications/learningspaces.pdf

Nelson B. \& McConachie, L. (2008). Space matters: Designing a high school library for learning. Educational Facility Planner. 44 (1), 21-24. 
Opening the Book. (n.d.) School library design. Retrieved June 6, 2016 from http://www.openingthebook.com/school-library-design

Partnership for the $21^{\text {st }}$ Century Skills. (n.d.). 21 st century learning environments. Retrieved June 5, 2016 from http://www.p21.org/storage/documents/le white paper-1.pdf

Smith System. (2014). Making the library commons an innovative and engaging learning environment. Retrieved from June 6, 2016 https://smithsystem.com/school\%20setting/libraries

Suarez, D. (2007). What students do when they study in the library: Using ethnographic methods to observe student behavior. Retrieved June 5, 2016 from http://southernlibrarianship.icaap.org/content/v08n03/suarez d01.html

Taylor, A. (2008). Linking architecture and education: Sustainable design of learning environments. Educational Facility Planner. 44 (1), 32-36.

Taylor-Powell, E. \& Renner, M. (2003). Analyzing qualitative data. Retrieved June 2, 2016 from http://learningstore.uwex.edu/assets/pdfs/g3658-12.pdf

Tongco, D. C. Purposive sampling as a tool for informant selection. Retrieved Jan. 14, 2015 from http://journals.sfu.ca/era/index.php/era/article/view/126/111

Van, N. \& Chism, N. (2006). Challenging traditional assumption and rethinking learning spaces. Retrieved March 3, 2016 from https://net.educause.edu/ir/library/pdf/pub7102.pdf Williams, D. \& Morrison, K. (2013). Impact of school libraries on learning. Retrieved June 5, 2016 from http://scottishlibraries.org/wp\%20content/uploads/2015/05/SLIC RGU Impact of School Libraries 2013.pdf 